\title{
Digestibility, Determination of Metabolizable Energy and Bone Mineralization of Broilers Fed with Nutritionally Valued Phytase
}

\section{-Author(s)}

Litz FH'
Fernandes EA'
Bueno JPR'
Silva MCA'
Carolino ACXG'
Martins JMS'"
Fagundes NS'II'
Nascimento Jr DV'

Universidade Federal de Uberlândia

" Universidade Federal de Goiás

II' Universidade de São Paulo

\section{Mail Address}

Corresponding author e-mail address Fernanda Heloisa Litz

Rua dos Carrijos, 471 - apt. 301, Saraiva, Uberlândia-MG, Brasil 38408-054

Tel: $\quad$ (55 34) 996769715

Email: fernandalitz@veterinaria.med.br

\section{neywords}

Animal nutrition, dicalcium phosphate, meatand-bone meal, tibia.

\section{ABSTRACT}

The objective of this study was to evaluate the effect of using exoenzyme phytase in broiler's diets on digestibility of nutrients, feed energy and tibia bone mineralization. A completely randomized design was used, with the following treatments: sorghum with dicalcium phosphate (SDP), corn with dicalcium phosphate (CDP), sorghum with meat and bone meal (SMBM), sorghum with valued phytase (SVP) and sorghum with phytase without valued (SPWV). For digestibility analysis, eighty 15 day old broilers were used, a total of 1400 male Hubbard Flex chickens, which were submitted to total excreta collection to obtain the percentages of food digestibility, crude protein, ether extract, apparent metabolizable energy, calcium and phosphorus while for tibias mineralization. Six birds per treatment were used, where determination of mineral matter, calcium and phosphorus were performed. Metabolizable energy (ME) and apparent metabolizable energy corrected for nitrogen (AMEn) of the feed were also calculated. Data were subjected to variation analysis and the average compared by $5 \%$ Tukey test. There was no difference between treatments for the digestibility at 15-20 day old as well as for the feed energy values, but the diets with phytase had higher phosphorous percentage values for tibia bone mineralization, demonstrating that exogenous phytase enzyme is able to hydrolyze phytate origininated from plant and release the phosphorus for assimilation by animals, acting as a substitute for phosphorus plant sources.

\section{INTRODUCTION}

Several studies regarding modern poultry are developed in the areas of genetics, management and nutrition; aimed at increasing productivity and reducing production costs through the maximum development of the animal's genetic potential.

Adequated nutrition is based on the principle that the animal is receiving a suitable amount of nutrients such as proteins, carbohydrates, lipids, vitamins and particularly minerals for participating of all biochemical body processes (Sechinato et al., 2006). Supplementation of macro minerals in poultry feed is frequently modified according to the genetic improvement as well as new knowledge of the physical and chemical characteristics of the sources that influence the bioavailability of these macro minerals for the animals (Bertechini \& Fassani, 2001).

Among the minerals required by poultry, phosphorus and calcium are the most important, not only because they are required for optimal growth rate, but also for bone mineralization. Phosphorus participates of metabolic processes and nutrients absorption, besides being the most expensive mineral in the feed's final cost (Gomes et al., 2004). 
Litz FH, Fernandes EA, Bueno JPR,

Silva MCA, Carolino ACXG,

Martins JMS, Fagundes NS,

Nascimento Jr DV
Digestibility, Determination of Metabolizable Energy and Bone Mineralization of Broilers Fed with Nutritionally Valued Phytase
The search for solutions to correctly fit phosphorus and calcium needs in the animal's body is constant, especially due to their fast growth and the consequent reduction in their slaughter age. Thus, it emphasizes the importance of using best quality feeds and the use of additives that enable broilers to take advantage of the nutrients in feeds (Brandão et al., 2007).

In diets formulated for poultry, the available phosphorus supply by vegetable sources is not sufficient to meet the appropriate nutritional requirements for animal performance and bone mineralization. Thus, there is a need for supplementation with phosphorus sources in the inorganic form, highlighting the differences in the values of bioavailability between these sources (Rostagno et al., 2005).

The production of endogenous phytase enzyme by birds is almost null and P complexed in form of phytate, which is considered the largest reserve of this element in plants, becomes unavailable for the animals, that is why the exogenous phytase administered via feed has been used as a phosphorus supplementation source (Conte et al., 2002), acting in the hydrolysis of phytate present in grains and releasing $\mathrm{P}$ for animal's assimilation.

Nutritionally, using exogenous enzymes such as phytase, for example, allows nutrients to be better used by the animal, so there would be an increase in the use of phosphorus, as well as amino acids and energy, reducing the feed formulation's final cost (Tejedor et al., 2001).

Therefore, the objective of this study was to evaluate the effect of using exoenzyme phytase in diets for broilers regarding the nutrient's digestibility, feed energy and tibia bone mineralization.

\section{MATERIAL AND METHODS}

The experiment was performed at the Experimental Farm Gloria - Poultry Research Farm in the Federal University of Uberlândia, in Uberlândia - MG, from September to October 2011 in accordance with ethical standards and approved by the Ethics Committee on Animal Use - CEUA-UFU, under research protocol number 077/11.

The birds were raised in a $60 \times 10$ meters barn, covered with metal structure and fibro-cement tiles, concreted floor, sided with masonry short walls and with four square centimeters wire mesh. The barn was internally equipped with 80 pens, each one measuring $1.90 \times 1.50$ meters, fans and water sprinklers to control the temperature, internal and external avian curtains. Each pen was composed of a tubular feeder of $20 \mathrm{~kg}$ and a pendular drinker, and for four pens there was an infrared hood. Rice shell was used as the litter material.

To perform this study, a performance research provided 1400 male chicks which were housed at one day old (average initial weight $43 \mathrm{~g}$ ) from Hubbard Flex lineage. These birds were from a multiplier company from Uberlândia, State of Minas Gerais, and vaccinated against Marek's disease and Gumboro at the hatchery.

A feeding program with four phases was used: pre-starter (1-7 days), starter (8-21 days), fattening (22-35 days) and slaughter (36-42 days). The diets were formulated with energy and nutrient levels based on Rostagno's et al. (2005) recommendations and according to each treatment (Tables 1, 2 and 3), they were calculated from bromatological analysis, performed at the Animal Nutrition Laboratory of the Faculty of Veterinary Medicine at UFU - LAMRA. During the experimental period the birds received feed and drinking water ad libitum.

The birds handling practices in the experiment period followed the model recommended by the Experimental Farm to ensure proper ambience to every stage of life, fresh and clean water supply, and feed ad libitum.

The birds were reared in three pens in order to develop the digestibility test. Fourty male chicks were allocated in each pen, fed with control diet (sorghum based feed / soybean meal + dicalcium phosphate) under 12 days, when four birds from each pen were transferred to test cages, with similar weights previously selected with an average weight of the three pens $( \pm$ $5 \%$ of variation). Thus, the design was randomized composed of five treatments: SDP (feed sorghum / soybean meal + dicalcium phosphate), CDP (corn based feed / soybean meal + dicalcium phosphate), SMBM (sorghum based feed / soybean meal + meat and bone meal), SVP (sorghum based feed / soybean meal + valued phytase) and SPWV (sorghum based feed / soybean meal + phytase without enrichment) and four replications. The corn feed was used as a performance control and as a comparative effect with sorghum. The valued phytase differs from the non valued phytase because in the first, to achieve the same energy level, the ingredients are altered compared to the control diet (SDP), because the inclusion by the enzyme action is expected, whereas in the second, the enzyme is added without altering the ingredients (Junqueira et al., 2010). 
Litz FH, Fernandes EA, Bueno JPR,

Silva MCA, Carolino ACXG,

Martins JMS, Fagundes NS,

Nascimento Jr DV

\section{Digestibility, Determination of Metabolizable Energy and Bone Mineralization of Broilers Fed with Nutritionally Valued Phytase}

Table 1 - Ingredients, percentage composition and calculated nutritional values of sorghum based feed (A) and corn based (B) with inorganic phosphate feed for broilers in the pre-starter phase (1-7 days), starter (8-21 days), fattening (22 to 35 days ) and slaughter (36 to 42 days).

\begin{tabular}{|c|c|c|c|c|c|c|c|c|}
\hline \multirow[t]{2}{*}{ Ingredients (\%) } & \multicolumn{2}{|c|}{ Pre-starter } & \multicolumn{2}{|c|}{ Starter } & \multicolumn{2}{|c|}{ Fattening } & \multicolumn{2}{|c|}{ Slaughter } \\
\hline & $A$ & $B$ & $A$ & $B$ & $A$ & $B$ & $A$ & $B$ \\
\hline Sorghum $8,6 \% C P$ & 54,33 & - & 56,63 & - & 58,71 & - & 61,65 & - \\
\hline Corn grain $8,0 \% \mathrm{CP}$ & - & 56,42 & - & 58,74 & - & 61,59 & - & 64,96 \\
\hline Soybean meal $46,5 \mathrm{CP}$ & 37,21 & 37,33 & 34,39 & 34,58 & 31,17 & 31,06 & 28,55 & 28,19 \\
\hline Soybean oil & 4,12 & 2,00 & 5,11 & 2,92 & 6,53 & 3,86 & 6,72 & 3,87 \\
\hline Dicalcium phosphate & 1,94 & 1,84 & 1,58 & 1,47 & 1,34 & 1,23 & 1,10 & 0,98 \\
\hline Limestone & 0,77 & 0,83 & 0,82 & 0,88 & 0,78 & 0,85 & 0,71 & 0,78 \\
\hline Salt & 0,46 & 0,44 & 0,44 & 0,42 & 0,42 & 0,40 & 0,41 & 0,39 \\
\hline L-lysine HCL & 0,32 & 0,31 & 0,27 & 0,26 & 0,27 & 0,26 & 0,26 & 0,25 \\
\hline DL-Methionine & 0,21 & 0,19 & 0,16 & 0,13 & 0,17 & 0,15 & 0,21 & 0,19 \\
\hline L-Threonine & 0,12 & 0,12 & 0,09 & 0,09 & 0,08 & 0,08 & 0,06 & 0,07 \\
\hline Px FC - Agroceres & $0,50^{1}$ & $0,50^{1}$ & $0,50^{1}$ & $0,50^{1}$ & $0,50^{2}$ & $0,50^{2}$ & $0,30^{3}$ & $0,30^{3}$ \\
\hline TOTAL & 100 & 100 & 100 & 100 & 100 & 100 & 100 & 100 \\
\hline \multicolumn{9}{|c|}{ Calculated nutritional composition (\%) } \\
\hline Crude Protein & 22,50 & 22,40 & 21,28 & 21,20 & 20,08 & 19,80 & 19,12 & 18,75 \\
\hline Calcium & 0,92 & 0,92 & 0,84 & 0,84 & 0,76 & 0,76 & 0,66 & 0,66 \\
\hline Available phosphorus & 0,47 & 0,47 & 0,40 & 0,40 & 0,35 & 0,35 & 0,31 & 0,31 \\
\hline Potassium & 0,86 & 0,85 & 0,81 & 0,81 & 0,76 & 0,75 & 0,72 & 0,71 \\
\hline Sodium & 0,22 & 0,22 & 0,21 & 0,21 & 0,20 & 0,20 & 0,19 & 0,19 \\
\hline Chlorine & 0,28 & 0,31 & 0,27 & 0,30 & 0,26 & 0,29 & 0,25 & 0,28 \\
\hline Linoleic acid & 3,11 & 1,77 & 3,66 & 2,27 & 4,43 & 2,77 & 4,54 & 2,78 \\
\hline Digestible lysine & 1,32 & 1,32 & 1,21 & 1,21 & 1,13 & 1,13 & 1,06 & 1,06 \\
\hline Digestible methionine & 0,67 & 0,66 & 0,60 & 0,59 & 0,57 & 0,56 & 0,53 & 0,51 \\
\hline Methionine + cystine & 0,95 & 0,95 & 0,87 & 0,87 & 0,91 & 0,82 & 0,77 & 0,77 \\
\hline Digestible threonine & 0,86 & 0,86 & 0,79 & 0,79 & 0,73 & 0,73 & 0,69 & 0,69 \\
\hline Digestible Tryptophan & 0,25 & 0,24 & 0,24 & 0,23 & 0,22 & 0,21 & 0,21 & 0,19 \\
\hline Digestible Arginine & 1,40 & 1,41 & 1,31 & 1,33 & 1,22 & 1,23 & 1,14 & 1,14 \\
\hline AME (Mcal kg-1) & 2,96 & 2,96 & 3,05 & 3,05 & 3,15 & 3,15 & 3,20 & 3,20 \\
\hline
\end{tabular}

"AME - Apparent metabolizable energy

'VitA 1.600.000,00 IU kg-1, VitB1 600,000 mg kg-1, VitB12 2.000,00 mcg kg-1, VitB2 800,00 $\mathrm{mg} \mathrm{kg}^{-1}$, VitB6 400,000 mg kg-1, VitD3 400.000,00 IU kg-1, VitE 3.000,00mg kg-1,

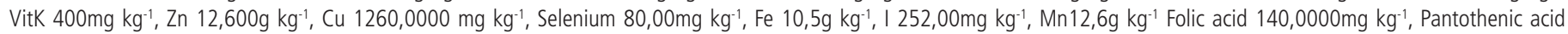

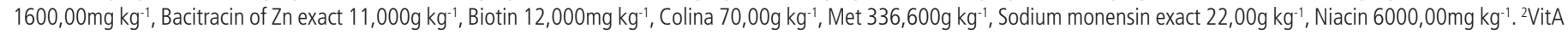
$1.280 .000,00 \mathrm{IU} \mathrm{kg}^{-1}$, VitB1 400,000 mg kg-1, VitB12 1.600,00 mcg kg-1, VitB2 720,00 $\mathrm{mg} \mathrm{kg}^{-1}$, VitB6 320,000 mg kg-1, VitD3 350.000,00 IU kg-1, VitE 2.400,00mg kg-1, VitK 300 mg

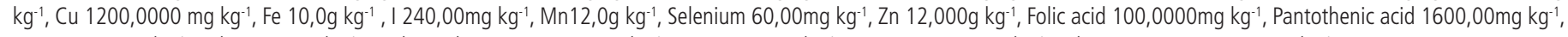

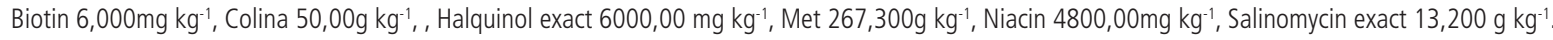

${ }^{3}$ VitA $1.300 .260,00 \mathrm{IU} \mathrm{kg}^{-1}$, VitB1 166,000 mg kg-1, VitB12 1.667,00 $\mathrm{mcg} \mathrm{kg}^{-1}$, VitB2 666,800 $\mathrm{mg} \mathrm{kg}^{-1}$, VitB6 200,000 mg kg-1, VitD3 400.000,00 IU kg-1, VitE 2.167, 10mg kg-1, VitK

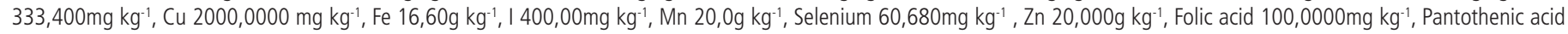
$1333,00 \mathrm{mg} \mathrm{kg}^{-1}$, Biotin 6,670 $\mathrm{mg} \mathrm{kg}^{-1}$, Colina 50,00 kg-1, Met 230,000 kg $\mathrm{g}^{-1}$, Niacin 4000,00 $\mathrm{mg} \mathrm{kg}^{-1}$, Virginiamycin exact 3.666,00 mg kg-1.

For the digestibility analysis, the total collection method of excreta in broilers was used with starting and ending time, determined by the appearance of tagged excreta (1\% Fe2O3 - Diets with Iron Oxide added). The data was collected in the period of 12 to 20 days (initial), consisting of three days of adaptation of the experimental diets and the new environment; and five days for excreta collection. Along with this analysis, an assay was performed to determine the value of the feed's Apparent Metabolizable Energy (AME) and Apparent Metabolizable Energy corrected for nitrogen (AMEn). The total collection of excreta from trays of each cage were taken out twice a day, caring about removing feathers and other foreign 
Litz FH, Fernandes EA, Bueno JPR,

Silva MCA, Carolino ACXG,

Martins JMS, Fagundes NS,

Nascimento Jr DV

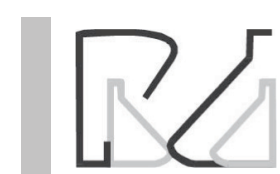

Digestibility, Determination of Metabolizable Energy and Bone Mineralization of Broilers Fed with Nutritionally Valued Phytase

Table 2 - Ingredients, percentage composition and calculated nutritional values of sorghum based feed and meat and bone based meal for broilers in pre-starter phase (1-7 days), starter (8-21 days), fattening (22 to 35 days) and slaughter (36 to 42 days).

\begin{tabular}{|c|c|c|c|c|}
\hline Ingredients (\%) & Pre-starter & Starter & Fattening & Slaughter \\
\hline Sorghum $8,6 \% C P$ & 56,75 & 58,59 & 60,38 & 63,03 \\
\hline Soybean meal 46,5 CP & 34,29 & 32,01 & 29,15 & 26,89 \\
\hline Soybean oil & 3,31 & 4,45 & 5,98 & 6,27 \\
\hline Meat and bone meal & 3,93 & 3,19 & 2,71 & 2,23 \\
\hline Limestone & 0,10 & 0,28 & 0,32 & 0,33 \\
\hline Salt & 0,41 & 0,39 & 0,38 & 0,38 \\
\hline L-lysine HCL & 0,35 & 0,30 & 0,29 & 0,28 \\
\hline DL-Methionine & 0,21 & 0,16 & 0,19 & 0,21 \\
\hline L-Threonine & 0,13 & 0,10 & 0,09 & 0,07 \\
\hline Px FC - Agroceres & $0,50^{1}$ & $0,50^{1}$ & $0,50^{2}$ & $0,30^{3}$ \\
\hline TOTAL & 100 & 100 & 100 & 100 \\
\hline \multicolumn{5}{|c|}{ Calculated nutritional composition (\%) } \\
\hline Crude protein & 22,862 & 21,577 & 20,334 & 19,332 \\
\hline Calcium & 0,920 & 0,841 & 0,758 & 0,663 \\
\hline Available phosphorus & 0,470 & 0,401 & 0,354 & 0,309 \\
\hline Potassium & 0,840 & 0,799 & 0,748 & 0,712 \\
\hline Sodium & 0,220 & 0,210 & 0,200 & 0,195 \\
\hline Chlorine & 0,272 & 0,261 & 0,251 & 0,246 \\
\hline Linoleic acid & 2,694 & 3,315 & 4,141 & 4,309 \\
\hline Digestible Lysine & 1,324 & 1,217 & 1,131 & 1,060 \\
\hline Digestible methionine & 0,672 & 0,607 & 0,575 & 0,534 \\
\hline Methionine+cystine & 0,953 & 0,876 & 0,826 & 0,774 \\
\hline Digestible threonine & 0,861 & 0,791 & 0,735 & 0,689 \\
\hline Digestible tryptophan & 0,246 & 0,233 & 0,219 & 0,208 \\
\hline Digestible arginine & 1,400 & 1,315 & 1,221 & 1,145 \\
\hline AME (Mcal kg-1) & 2,9600 & 3,0500 & 3,1500 & 3,2000 \\
\hline
\end{tabular}

"AME - Apparent metabolizable energy

1,2 and ${ }^{3}$ : idem Table 1.

bodies in the tray, and then placed in labeled plastic bags, weighed for excreta quantification in grams and frozen for storage and later analysis.

At the laboratory (LAMRA), excreta were defrosted and homogenized. Samples were taken and pre-dried in forced ventilation oven at $56{ }^{\circ} \mathrm{C}$ for 72 hours and then ground in a knife mill to perform the analyzes of dry matter, ether extract, crude protein, crude fiber, ash, calcium, phosphorus according to the methodology proposed by the Brazilian Compendium of Animal Nutrition (Brasil, 2005) and gross energy by bomb calorimeter IKA-Werke C2000 basic. The feed digestibility was calculated as follows:

Digestibility $=(($ ingested nutrient quantity - Excreted $)$ / ingested nutrient Quantity) * 100

From the excreta gross energy, the values of Apparent Metabolizable Energy (AME) and Apparent Metabolizable Energy corrected for nitrogen (AMEn) were determined.
At 42 days of age, the birds were slaughtered according to official procedures; six males were chosen with weights into the treatment average for analysis of the tibia's mineralization, which were removed, cleaned and sectioned by the epiphysis of the left tibias. The diaphysis of these tibias were dried in forced ventilation oven at $56^{\circ} \mathrm{C}$ for 72 hours and then placed in containers with petroleum ether for fat extraction. Subsequently, they were placed in an oven at $600^{\circ} \mathrm{C}$ for 4 hours to determine the mineral matter content (\% MM), and from the ash, the calcium (Ca\%) and phosphorus (P\%) content was determined, following the Brazilian Compendium of Animal Nutrition (Brasil, 2005) methodology.

All data were submitted to variances homogeneity checking, residuals normality and then analysis of variance was performed and the averages compared by Tukey test at $5 \%$. 
Litz FH, Fernandes EA, Bueno JPR,

Silva MCA, Carolino ACXG,

Martins JMS, Fagundes NS,

Nascimento Jr DV

\section{Digestibility, Determination of Metabolizable Energy and Bone Mineralization of Broilers Fed with Nutritionally Valued Phytase}

Table 3 - Ingredients, percentage composition and calculated nutritional values of sorghum based feed and phytase with energy and amino acids enrichment (A); and phytase without energy enrichment and amino acids (B) for broilers in the prestarter phase (1-7 days), starter (8-21 days), fattening (22 to 35 days) and slaughter (36 to 42 days).

\begin{tabular}{|c|c|c|c|c|c|c|c|c|}
\hline \multirow[t]{2}{*}{ Ingredients (\%) } & \multicolumn{2}{|c|}{ Pre-starter } & \multicolumn{2}{|c|}{ Starter } & \multicolumn{2}{|c|}{ Fattening } & \multicolumn{2}{|c|}{ Slaughter } \\
\hline & $A$ & B & $A$ & $B$ & A & B & $A$ & B \\
\hline Sorghum $8,6 \% \mathrm{CP}$ & 55,58 & 54,62 & 57,88 & 56,92 & 60,08 & 59,57 & 63,02 & 62,52 \\
\hline Soybean meal $46,5 \mathrm{CP}$ & 37,09 & 37,18 & 34,27 & 34,36 & 31,03 & 31,08 & 28,41 & 28,46 \\
\hline Soybean oil & 3,46 & 4,02 & 4,45 & 5,012 & 5,84 & 6,25 & 6,03 & 6,44 \\
\hline Dicalcium phosphate & 1,44 & 1,44 & 1,07 & 1,08 & 0,78 & 0,78 & 0,54 & 0,55 \\
\hline Limestone & 0,83 & 1,09 & 0,89 & 1,14 & 0,84 & 0,84 & 0,77 & 0,77 \\
\hline Salt & 0,46 & 0,46 & 0,44 & 0,44 & 0,42 & 0,42 & 0,41 & 0,41 \\
\hline L-lysine $\mathrm{HCL}$ & 0,31 & 0,32 & 0,26 & 0,27 & 0,25 & 0,27 & 0,24 & 0,26 \\
\hline DL-Methionine & 0,20 & 0,21 & 0,15 & 0,15 & 0,17 & 0,17 & 0,20 & 0,21 \\
\hline L-Threonine & 0,10 & 0,12 & 0,07 & 0,08 & 0,06 & 0,07 & 0,05 & 0,06 \\
\hline Px FC - Agroceres & $0,50^{1}$ & $0,50^{1}$ & $0,50^{1}$ & $0,50^{1}$ & $0,50^{2}$ & $0,50^{2}$ & $0,30^{3}$ & $0,30^{3}$ \\
\hline Microtech 500 & 0,01 & 0,01 & 0,01 & 0,01 & 0,01 & 0,01 & 0,01 & 0,01 \\
\hline TOTAL & 100 & 100 & 100 & 100 & 100 & 100 & 100 & 100 \\
\hline \multicolumn{9}{|c|}{ Calculated nutritional composition (\%) } \\
\hline Crude Protein & 22,74 & 22,51 & 21,53 & 21,29 & 20,34 & 20,11 & 19,39 & 19,16 \\
\hline Calcium & 0,92 & 0,92 & 0,84 & 0,84 & 0,76 & 0,76 & 0,66 & 0,66 \\
\hline Available phosphorus & 0,47 & 0,47 & 0,40 & 0,40 & 0,35 & 0,35 & 0,31 & 0,31 \\
\hline Potassium & 0,86 & 0,86 & 0,81 & 0,81 & 0,76 & 0,76 & 0,72 & 0,72 \\
\hline Sodium & 0,22 & 0,22 & 0,21 & 0,21 & 0,20 & 0,20 & 0,19 & 0,19 \\
\hline Chlorine & 0,28 & 0,28 & 0,27 & 0,27 & 0,26 & 0,26 & 0,25 & 0,25 \\
\hline Linoleic acid & 2,77 & 3,06 & 3,31 & 3,61 & 4,68 & 4,28 & 4,18 & 4,40 \\
\hline Digestible lysine & 1,32 & 1,32 & 1,21 & 1,21 & 1,13 & 1,13 & 1,06 & 1,06 \\
\hline Digestible methionine & 0,67 & 0,67 & 0,60 & 0,60 & 0,57 & 0,57 & 0,53 & 0,53 \\
\hline Methionine + cystine & 0,95 & 0,95 & 0,87 & 0,87 & 0,82 & 0,82 & 0,77 & 0,77 \\
\hline Digestible threonine & 0,86 & 0,86 & 0,79 & 0,79 & 0,73 & 0,73 & 0,69 & 0,69 \\
\hline Digestible Tryptophan & 0,25 & 0,25 & 0,24 & 0,24 & 0,22 & 0,22 & 0,21 & 0,21 \\
\hline Digestible Arginine & 1,40 & 1,40 & 1,31 & 1,31 & 1,22 & 1,22 & 1,14 & 1,14 \\
\hline AME (Mcal kg-1) & 2,96 & 2,96 & 3,05 & 3,05 & 3,15 & 3,15 & 3,20 & 3,20 \\
\hline
\end{tabular}

"AME - Apparent metabolizable energy

1,2 and ${ }^{3}$ : idem Table 1.

\section{RESULTS AND DISCUSSION}

From 15-20 days of age, there was no difference in feed digestibility, crude protein, ether extract, apparent metabolizable energy, calcium and phosphorus among the diets (Table 4), demonstrating that the phytase enzyme, when participated in the nutritional matrix feed, could provide the nutrients to the birds at the starter phase period, and there was no difference between the phosphorus sources used.

The digestibility results of this study from 15-20 days of age are according to Adeola \& Sands (2003) ones, in the case of using phytase enzyme, since they did not observe improvement in amino acid's and protein's

Table 4 - Percentage of feed digestibility values (FD\%), crude protein (CP\%), ether extract (EE\%), apparent metabolizable energy (AME\%), Calcium (Ca\%) and phosphorus (P\%) of broilers at 15-20 days of age, fed diets with different phosphorus and phytase sources.

\begin{tabular}{|c|c|c|c|c|c|c|}
\hline Treatment & FD\% & CPD\% & EED\% & AMED\% & $\mathrm{CaD} \%$ & PD\% \\
\hline SDP & 72,25 & 60,74 & 78,83 & 74,55 & 58,58 & 65,55 \\
\hline CDP & 72,54 & 61,00 & 79,43 & 74,45 & 58,21 & 66,95 \\
\hline SMBM & 72,29 & 64,31 & 84,43 & 77,12 & 61,95 & 70,18 \\
\hline SVP & 72,49 & 61,07 & 81,80 & 74,59 & 57,85 & 65,61 \\
\hline SPWV & 73,54 & 63,03 & 78,66 & 75,45 & 59,96 & 66,82 \\
\hline$C V$ & 3,435 & 6,250 & 5,111 & 2,953 & 7,016 & 5,067 \\
\hline Pvalue & 0,4399 & 0,6691 & 0,2462 & 0,4145 & 0,6701 & 0,3039 \\
\hline
\end{tabular}

SDP (sorghum based feed / soybean meal + dicalcium phosphate) CDP (corn based feed / soybean meal + dicalcium phosphate) SMBM (sorghum based feed / soybean meal + meat and bone meal), SVP (sorghum based feed / soybean meal + enriched phytase) and SPWV (sorghum based feed / soybean meal + phytase without enrichment). 
Litz FH, Fernandes EA, Bueno JPR,

Silva MCA, Carolino ACXG,

Martins JMS, Fagundes NS,

Nascimento Jr DV

\section{Digestibility, Determination of Metabolizable Energy and Bone Mineralization of Broilers Fed with Nutritionally Valued Phytase}

digestibility using this enzyme. Similarly, Boling et al. (2000) reported that supplementation of diets with phytase did not improve ileal digestibility of amino acids in chicks.

In contrast, Tejedor et al. (2001) evaluated 10-24 day old chickens, and found better digestibility values of calcium, phosphorus, protein and apparent energy with the addition of phytase (500-750 uft kg-1 (unit of phytase per $\mathrm{kg}$ )) and a better utilization of protein, for example, by breaking the nutrient complex (proteinphytic acid) by the use of phytase breaking and releasing phytate protein and amino acids.

Ferlin (2006) and Viveiros et al. (2002) showed that the use of phytase increased the diet's total digestibility, improving the metabolization of nutrients and reducing the amount of nitrogen and phosphorus in bird excreta, reducing then, the contamination in the environment, which was not seen in this study.

In case of phosphorus and energy, Fukayama et al. (2008) showed that the improvement in digestibility of these nutrients is only possible when the phytase supplementation is performed using levels from 750 uft $\mathrm{kg}^{-1}$, whereas in our studies, the levels of enzyme used was 500 uft kg-1 $^{-1}$.

Meat bone meal may be used as phosphorus source in the starter phase of rearing, once similar results to diets with only dicalcium phosphate were obtained; demonstrating as well as Traylor et al. (2005), that the presence of bone in the feed formulation makes it a good source of minerals, particularly phosphorus, in addition to being economically viable since this ingredient is generally produced in a large scale.

The metabolizable energy and apparent metabolizable energy corrected for nitrogen from 15-20 days of age did not differ among the treatments (Table 5),

Table 5 - Metabolizable Energy Values (AME) and Apparent Metabolizable Energy corrected for nitrogen (AMEn) of diets with different sources of phosphorus and phytase enzyme to broilers from 15-20 days of age.

\begin{tabular}{lcc}
\hline Treatment & ME kcal/g MN & AMEn kcal/g MN \\
\hline SDP & 2,841 & 2,675 \\
CDP & 2,767 & 2,600 \\
SMBM & 2,939 & 2,758 \\
SVP & 2,808 & 2,638 \\
SPWV & 2,850 & 2,668 \\
\hline CV & 3,318 & 3,139 \\
p value & 0,0728 & 0,0574 \\
\hline
\end{tabular}

SDP (sorghum based feed / soybean meal + dicalcium phosphate) CDP (corn based feed / soybean meal + dicalcium phosphate) SMBM (sorghum based feed / soybean meal + meat and bone meal), SVP (sorghum based feed / soybean meal + enriched phytase) and SPWV (sorghum based feed / soybean meal + phytase without enrichment). so the enzyme phytase was not able to provide energy increase as enunciated by Tejedor et al. (2001), who worked with different breed of broiler chickens (Avian Farm) from the one used in this study.

Lan et al. (2002), when analyzing the metabolizable energy content in the corn and soybean based feed supplemented with phytase enzyme (250-1000 uft kg1) for Avian chickens in the initial and final phases, found higher values of apparent metabolizable energy when compared to a diet with normal levels of phosphorus and without enzyme supplementation.

Dourado et al. (2007) found that phytase provided the greatest increase in true metabolizable energy corrected for nitrogen balance (TMEn) of corn compared with other enzymes in broilers diets, in which we observed improvement of $95 \mathrm{kcal} \mathrm{kg-1}$ in TMEn adding phytase, while Viana et al. (2009) studying laying hens, reported that the addition of enriched phytase provides increased metabolism of energy and energy corrected by nitrogen balance.

In accordance with our studies, Lelis et al. (2010), working with Ross chickens from 16-25 days days of age, said that the diets supplemented with enriched phytase (250 and 500 uft kg-1) had similar values of apparent metabolizable energy corrected by nitrogen balance when compared to diets formulated only with inorganic phosphate.

After 42 days days of age, the treatment with phytase without enrichment showed highest deposition of calcium and phosphorus in the bone and did not differ by treatment with enriched phytase (Table 6), demonstrating that the enzyme was able to provide these birds with phosphorus, or the enzyme is able to hydrolyze phytate present in the grain and release phosphorus for the animal's absorption.

Table 6 - Percentage values of mineral matter (MM\%), calcium (Ca\%) and phosphorus (P\%) of tibia of broilers at 42 days days of age.

\begin{tabular}{lccc}
\hline Treatment & MM\% & Ca\% & P\% \\
\hline SDP & 43,93 & $16,80 b$ & $10,18 b$ \\
CDP & 44,87 & $17,79 b$ & $7,89 \mathrm{c}$ \\
SMBM & 45,96 & $18,90 \mathrm{ab}$ & $8,75 \mathrm{bc}$ \\
SVP & 45,94 & $19,39 a b$ & $10,32 \mathrm{ab}$ \\
SPWV & 47,18 & $21,92 \mathrm{a}$ & $12,04 \mathrm{a}$ \\
\hline CV & 6,216 & 13,69 & 17,755 \\
Pvalue & 0,3516 & $0,0030 *$ & $<0,0001$ * \\
\hline
\end{tabular}

SDP (sorghum based feed / soybean meal + dicalcium phosphate) CDP (corn based feed / soybean meal + dicalcium phosphate) SMBM (sorghum based feed / soybean meal + meat and bone meal), SVP (sorghum based feed / soybean meal + enriched phytase) and SPWV (sorghum based feed / soybean meal + phytase without enrichment). 
Litz FH, Fernandes EA, Bueno JPR,

Silva MCA, Carolino ACXG,

Martins JMS, Fagundes NS,

Nascimento Jr DV

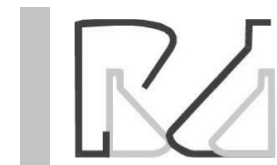

Digestibility, Determination of Metabolizable Energy and Bone Mineralization of Broilers Fed with Nutritionally Valued Phytase
According to Sohail \& Roland (1999), the bone characteristics are the most sensitive parameters to evaluate the effect of phytase compared to performance characteristics. Taking in consideration that $\mathrm{Ca}$ and $\mathrm{P}$ are the most prevalent minerals in the bone structure, the increased availability of these minerals by adding phytase enzyme justifies the higher percentage of ash, Ca and P in the tibia (Fukayama et al., 2008). The efficiency of phytase enzyme in hydrolyzing mineralphytic-acid complex, leaving them free for absorption and contributing to bone mineralization is evidenced, justifying higher percentages of $\mathrm{Ca}$ and $\mathrm{P}$ in the treatments with phytase.

Oliveira et al. (2008), evaluating the tibia bone density in their different areas (middle and distal epiphyseal and diaphyseal), observed that reducing the levels of available phosphorus in diets for broilers also reduces the density of the tibia regions, while the inclusion of phytase in the diet increases the density of different regions, since there were higher phosphorus supplies for bone deposition, demonstrating that the use of this enzyme increases the utilization of the organic phosphorus which is in the form of phytate, reducing the cost of adding inorganic phosphorus to the diet as elucidated by Brandão et al. (2007).

The exogenous phytase enzyme, when included in the nutritional matrix feed, is able to hydrolyze phytate plant and release phosphorus to be digested by broilers, thereby, acting as a substitute for phosphorus plant sources.

\section{REFERENCES}

Adeola O, Sands JS. Does supplemental dietary microbial phytase improve amino acid utilization? A perspective that it does not. Journal of Animal Science 2003;81(Suppl 2):78-85

Bertechini AG, Fassani EJ. Macro e microminerais na alimentação animal. Anais do 1st Simpósio Sobre Ingredientes na Alimentação Animal; 2001; Campinas: CBA; 2001. p.219-234.

Brandão PA, Costa FGP, Brandão JS, Silva JHV. Efeito da adição de fitase em rações de frangos de corte, durante as fases de crescimento e final. Ciência e Agrotecnologia 2007;31(2):492-498.

Brasil. Ministério da Agricultura e Abastecimento. Sindicato Nacional da Indústria de Alimentação Animal. Associação Nacional dos Fabricantes de Rações. Compêndio brasileiro de alimentação animal. São Paulo: ANFAR/CBNA/SDR; 2005.

Boling SD, Webel DM, Mavromichalis I, Parsons CM, Baker DH. The effects of citric acid on phytate-phosphorus utilization in young chicks and pigs. Journal of Animal Science 2000;78(3):682-689.

Conte AJ, Teixeira AS, Figueirêdo AV, Vitti DMSS, Silva Filho JC. Efeito da fitase na biodisponibilidade do fósforo do farelo de arroz em frangos de corte. Pesquisa Agropecuária Brasileira 2002;37(4):547-552.

Dourado LRB, Sakomura NK, Nascimento DCM, Dorigam JCP, Barbosa NAA, Marcato SM. Efeito de enzimas exógenas na disponibilidade da energia metabolizável verdadeira do milho e do farelo de soja. Anais da Conferência Apinco de Ciência e Tecnologia Avícolas; 2007; Santos: FACTA; 2007. p.126.

Ferlin M. Efeito da fitase sobre a utilização da energia metabolizável da dieta em frangos de corte [dissertation]. Pelotas (RS): Universidade Federal de Pelotas; 2006

Fukayama EH, Sakomura NK, Dourado LRB, Neme R, Fernandes JBK, Marcato SM. Efeito da suplementação de fitase sobre o desempenho e a digestibilidade dos nutrientes em frangos de corte. Revista Brasileira de Zootecnia 2008;37(4):629-635.

Gomes PC, Runho RC, Dagostini P, Rostagno HS, Albino LFT, Lopes PS. Exigência de fósforo disponível para frangos de corte machos e fêmeas de 22 a 42 e de 43 a 53 dias de idade. Revista Brasileira de Zootecnia 2004;33(6):1734-1746(Suppl 1).

Junqueira OM, Filardi RS, Ligeiro ES, Casartelli EM, Sgavioli S, Assuena V, et al. Avaliação técnica e econômica da matriz nutricional da enzima fitase em rações contendo farelo de girassol para poedeiras comerciais. Revista Brasileira de Zootecnia 2010;39(10):2200-6.

Lan GQ, Abdullah N, Jalaludin S, Ho YW. Efficacy of supplementation of a phytase-producing bacterial culture on the performance and nutrient use of broiler chickens fed corn-soybean meal diets. Poultry Science 2002;81(10):1522-1532

Lelis GR, Albino LFT, Silva CR, Rostagno HS, Gomes PC, Borsatto CG. Suplementação dietética de fitase sobre o metabolismo de nutrientes de frangos de corte. Revista Brasileira de Zootecnia 2010;39(8):17681773.

Oliveira MC, Marques RH, Gravena RA, Bruno LDG, Rodrigues EA, Moraes VMB. Qualidade óssea de frangos alimentados com dietas com fitase e níveis reduzidos de fósforo disponível. Acta Scientiarum. Animal Sciences 2008;30(3):263-268

Rostagno HS, Albino LFT, Donzele JL, Gomes PC, Oliveira RF, Lopes DC, et al. Tabelas brasileiras para aves e suínos:composição de alimentos e exigências nutricionais. 2nd ed. Viçosa: UFV; 2005. Available from: https://www.agencia.cnptia.embrapa.br/Repositorio/ Tabelas+brasileiras+-+Rostagno_000gy1 tqvm602wx7ha0b6gs0xfzo6 pk5.pdf

Sechinato AS, Albuquerque R, Nakada S. Efeito da suplementação dietética com micro minerais orgânicos na produção de galinhas poedeiras. Brazilian Journal Veterinary Research and Animal Science 2006;43(2):159-166.

Sohail SS, Roland DA. Influence of supplemental phytase on performance of broilers four to six weeks of age. Poultry Science 1999;78(4):550555 .

Tejedor AA, Albino LFT, Rostagno HS, Vieites FM. Efeito da adição da enzima fitase sobre o desempenho e a digestibilidade ileal de nutrientes. Revista Brasileira de Zootecnia 2001;30(3):802-808.

Traylor SL, Cromwell GL, Lindemann MD. Bioavailability of phosphorus in meat and bone meal for swine. Journal of Animal Science 2005;83 (5):1054-1061.

Viana MTS, Albino LFT, Rostagno HS, Barreto SLT, Silva EA, Florentino WM. Efeito da suplementação de enzima fitase sobre o metabolismo de nutrientes e o desempenho de poedeiras. Revista Brasileira Zootecnia 2009;36(6):1074-1080.

Viveros A, Brenes A, Arija I, Centeno C. Effects of microbial phytase supplementation on mineral utilization and serum enzyme activities in broiler chicks fed different levels of phosphorus. Poultry Science 2002;81(8):1172-1183. 
